\title{
Genome Size of Cyanobacteria
}

\author{
BY MICHAEL HERDMAN,* MONIQUE JANVIER, \\ ROSMARIE RIPPKA AND ROGER Y.STANIER \\ Unité de Physiologie Microbienne, Département de Biochimie et Génétique Microbienne, \\ Institut Pasteur, 28 rue du Docteur Roux, Paris 75015, France
}

(Received 8 June 1978)

\begin{abstract}
The genome sizes of 128 strains of cyanobacteria, representative of all major taxonomic groups, lie in the range $1.6 \times 10^{9}$ to $8.6 \times 10^{9}$ daltons. The majority of unicellular cyanobacteria contain genomes of $1.6 \times 10^{9}$ to $2.7 \times 10^{9}$ daltons, comparable in size to those of other bacteria, whereas most pleurocapsalean and filamentous strains possess larger genomes. The genome sizes are discontinuously distributed into four distinct groups which have means of $2.2 \times 10^{9}, 3.6 \times 10^{9}, 5.0 \times 10^{9}$ and $7.4 \times 10^{9}$ daltons. The data suggest that genome evolution in cyanobacteria occurred by a series of duplications of a small ancestral genome, and that the complex morphological organization characteristic of many cyanobacteria may have arisen as a result of this process.
\end{abstract}

\section{INTRODUCTION}

All bacteria possess genomes which are relatively uniform in size, varying from $1.0 \times 10^{9}$ to $3.6 \times 10^{9}$ daltons (see Gillis et al., 1970; Wallace \& Morowitz, 1973). The only exception is a group of Mycoplasma strains which contain small genomes of $0.4 \times 10^{9}$ to $0.5 \times 10^{9}$ daltons (Bak et al., 1969). Bak et al. (1970) listed a number of bacterial species which appeared to contain much larger genomes, but these species were subsequently shown to fall within the normal bacterial range of genome size (Gillis et al., 1970; Pemberton, 1974).

The genomes of several strains of cyanobacteria previously examined are similar in size to those of other bacteria. The DNA of Anacystis nidulans (classified in this communication as Synechococcus PCC 6301) and Lyngbya sp. renatured with kinetics approximately similar to those of bacterial DNA (Kung et al., 1972), although quantitative estimates of genome size were not obtained. The genome sizes of A. nidulans (Synechococcus PCC 6301) and Anabaena cylindrica (PCC 7122) were estimated to be $2.27 \times 10^{9}$ and $2.47 \times 10^{9}$ daltons, respectively (Herdman \& Carr, 1974). The DNA of these strains renatured as a single kinetic class, suggesting the absence of reiterated DNA sequences, although such sequences may not have been detected because the early stages of the renaturation reaction were not followed. Roberts et al. (1977) reported that the DNA of Agmenellum quadruplicatum (classified here as Synechococcus PCC 7002) had a kinetic complexity within the range $2.2 \times 10^{9}$ to $2.8 \times 10^{9}$ daltons, and that reiterated DNA sequences were absent.

This communication describes the genome sizes of 128 strains of cyanobacteria, representative of all major taxonomic groups, as measured from the kinetics of renaturation of DNA. The results are compared with values previously obtained for other bacteria, and the taxonomic and evolutionary implications are discussed.

* Present address: Department of Biological Sciences, The University, Dundee DD1 4HN. 


\section{METHODS}

Organisms and culture conditions. The strains examined are listed in Tables 1 to 5. Their generic assignments, properties, strain histories and media employed for cultivation are fully described by Rippka et al. (1979), with the exception of Oscillatoria agardhii PCC 7805 which is described by Herdman et al. (1979).

Extraction of DNA. DNA was extracted and purified by the hydroxyapatite method described by Herdman et al. (1979) and stored in $0 \cdot 1 \times \mathrm{SSC}$ buffer (SSC buffer, $\mathrm{pH} 7 \cdot 0$, is $0 \cdot 15 \mathrm{M}-\mathrm{NaCl} / 0 \cdot 015 \mathrm{M}$-trisodium citrate) over chloroform at $4{ }^{\circ} \mathrm{C}$.

Estimation of genome size. Genome sizes were measured from the kinetics of renaturation of thermally denatured DNA. Purified DNA samples in $0 \cdot 1 \times \mathrm{SSC}$ buffer were normally adjusted to a concentration of 50 to $65 \mu \mathrm{g} \mathrm{ml}^{-1}$ and the native DNA was fragmented by passage through a French press at $145 \mathrm{MPa}$ (Gillis et al., 1970). DNA samples $(1.2 \mathrm{ml})$ were placed in sealed $1.5 \mathrm{ml}$ cuvettes $(1 \mathrm{~cm}$ light path) in a Gilford 240 spectrophotometer fitted with an automatic cuvette programmer, thermosensor and analogue multiplexer. The samples were equilibrated to $T_{m}-20^{\circ} \mathrm{C}$ (where $T_{m}$ is the temperature midpoint of thermal denaturation) and then thermally denatured by raising the temperature to $T_{m}+20^{\circ} \mathrm{C}$. The change in absorbance at $260 \mathrm{~nm}$ was recorded. After complete denaturation, the solutions were equilibrated to the optimal temperature for renaturation $\left(T_{\mathrm{OR}}\right)$ in the presence of $1 \mathrm{M}-\mathrm{Na}^{+}$, and then prewarmed $5 \mathrm{M}-\mathrm{NaCl}$ was added to raise the $\mathrm{Na}^{+}$ concentration to $1 \mathrm{M}$. Renaturation commenced immediately and the resulting change in absorbance $\left(\Delta A_{260}\right)$ was recorded. The $T_{m}$ in $1 \mathrm{M}-\mathrm{Na}^{+}$was calculated from the equation

$$
\% \mathrm{GC}=2 \cdot 44\left(T_{m}-81 \cdot 5-16 \cdot 6 \log \mathrm{M}\right)
$$

where $\mathrm{M}$ is the molar concentration of $\mathrm{Na}^{+}$(Marmur \& Doty, 1962), and the $T_{\mathrm{OR}}$ in $1 \mathrm{M}-\mathrm{Na} a^{+}$was calculated from $T_{\mathrm{OR}}=T_{m}-25^{\circ} \mathrm{C}$ (Wetmur \& Davidson, 1968), using the values of mean DNA base composition determined by Herdman et al. (1979). Three DNA samples were examined in each experiment; the fourth cuvette contained a solution of guanine $\left(1.2 \mathrm{ml}, A_{260} 1.3\right)$ to enable correction to be made for solvent expansion and electronic drift.

The second-order renaturation rate constant, $k_{2}$, was calculated from the equation

$$
\frac{A_{0}-A_{\infty}}{A-A_{\infty}}=\frac{k_{2} \mathrm{P}_{\mathrm{T}}}{2} t+1
$$

where $A_{\infty}$ and $A_{0}$ are the absorbances of native and denatured DNA, respectively, $A$ is the absorbance of the solution at time $t$ and $\mathrm{P}_{\mathrm{T}}$ is the total DNA phosphate concentration (Wetmur \& Davidson, 1968). The genome mol. wt was calculated by reference to an Escherichia coli control of known genome size (strain W1485, 2.40 $\times 10^{9}$ daltons) using the equation $k_{\mathrm{A}} / k_{\mathrm{B}}=M_{\mathrm{B}} / M_{\mathrm{A}}$ (Gillis et al., 1970) where $k_{\mathrm{A}}, k_{\mathrm{B}}, M_{\mathrm{A}}$ and $M_{\mathrm{B}}$ represent the second-order renaturation rate constants $(k)$ and genome mol, wts $(M)$ of the control (A) and test organisms (B), respectively. The genome size $\left(N_{\mathrm{D}}\right)$ of the $E$. coli control was calculated from the alkaline sedimentation velocity and $k_{2}$ using the equation (Wetmur \& Davidson, 1968)

$$
N_{\mathrm{D}}=\frac{5.5 \times 10^{8}\left(S_{20, \mathrm{w}}^{\mathrm{pH} 13}\right)^{1 \cdot 25}}{k_{2}}
$$

The results obtained were not corrected for any possible effect of base composition on renaturation rate since it has been shown (Gillis \& De Ley, 1975) that this effect is negligible.

Control of the method. DNA concentration and fragment size, ionic strength of solvent and $T_{\mathrm{OR}}$ were rigorously controlled throughout. The purity of the DNA samples was routinely verified as described by Herdman et al. (1979); no contamination with protein or RNA was detectable in any sample. The high reproducibility of the method (as shown by low standard deviations from the mean in Tables 1 to 5) was achieved by initiating the renaturation reaction by elevation of $\mathrm{Na}^{+}$concentration rather than by thermal change, permitting the reaction to be recorded within $30 \mathrm{~s}$ of initiation. This technique also permitted the detection of reiterated DNA sequences which renatured rapidly in the early stages of the reaction.

For some strains, an independent estimate of genome size was obtained by chemical measurement (Burton, 1956, as described by Mann \& Carr, 1974) of the minimum cell DNA content, corresponding to a single genome. This was achieved by measuring the cell DNA content at different growth rates; the intercept of the plot of $\log$ DNA content versus growth rate represents the single genome contained by cells at zero growth rate (Mann \& Carr, 1974). 


\section{RESULTS AND DISCUSSION}

The reliability of the method was verified with DNA extracted from $E$. coli W1485 and $P$ seudomonas aeruginosa 6352 . The genome size of $E$. coli was $2 \cdot 40 \times 10^{9}$ daltons, as estimated from the alkaline sedimentation velocity and $k_{2}$; this is in agreement with previous estimates (Gillis et al., 1970). Renaturation of $P$. aeruginosa DNA revealed a genome of $2.54 \times 10^{9}$ daltons. This value differs from that $\left(6.96 \times 10^{9}\right.$ daltons $)$ previously obtained from renaturation kinetics (Bak et al., 1970) but is in close agreement with the estimate of $2.1 \times 10^{9}$ daltons obtained by electron microscope observation and velocity sedimentation analysis (Pemberton, 1974) and is similar to the values obtained for $P$. fluorescens $\left(2 \cdot 72 \times 10^{9}\right.$ daltons) and $P$. putida $\left(2 \cdot 53 \times 10^{9}\right.$ daltons) by Gillis et al. (1970).

Further verification of the accuracy of the renaturation method was obtained by comparison with the genome size derived from chemical estimates of cell DNA content at different growth rates by extrapolation to zero growth rate as described by Mann \& Carr (1974). The estimated genome sizes for Synechococcus PCC $6301\left(2.08 \times 10^{9}\right.$ daltons), Anabaena PCC $7118\left(3.61 \times 10^{9}\right.$ daltons) and Nostoc PCC $7524\left(5.80 \times 10^{9}\right.$ daltons) corresponded closely to the kinetic complexity values of $2 \cdot 12 \times 10^{9}, 3 \cdot 74 \times 10^{9}$ and $5.61 \times 10^{9}$ daltons, respectively.

The genome sizes of cyanobacteria of Sections $I$ to $V$ are shown in Tables 1 to 5 . Within the tables, the genera have been divided into their different DNA base compositional subgroups (Herdman et al., 1979) where possible; within each genus or sub-group the strains are arranged in order of increasing genome size. Strains which appear, by other criteria, to be closely related (Rippka et al., 1979) are enclosed by braces, although specific names have not been appended. Some strains, originally thought to be of independent origin, are now considered to be identical isolates (Rippka et al., 1979) and in these cases the data for only one such strain are given.

\section{Genome sizes of cyanobacteria assigned to Section I}

Section I contains six genera of unicellular cyanobacteria which reproduce either by binary fission (most genera) or by budding (Chamaesiphon). The genome sizes are shown in Table 1.

The genus Synechococcus (sheathless unicellular cyanobacteria which divide by binary fission in only one plane) has been divided into three groups of different DNA base composition (Herdman et al., 1979). The five strains of sub-group 1 (39 to $43 \mathrm{~mol} \% \mathrm{GC}$ ) vary in genome size from $2.55 \times 10^{9}$ to $4.20 \times 10^{9}$ daltons, and the mean genome size $\left(3.16 \times 10^{9}\right.$ daltons) is larger than that of the other Synechococcus sub-groups. The wide variation in genome size of the members of this sub-group is accompanied by diversity in other phenotypic properties (Rippka et al., 1979). Strains 7418 and 7424, which contain large genomes of $3.08 \times 10^{9}$ and $4.20 \times 10^{9}$ daltons, respectively, are readily distinguished from the remaining strains by their large cell size, and strain 7424 is further distinguished by its ability to fix nitrogen under anaerobic conditions (Rippka \& Waterbury, 1977). Strain $7511\left(3 \cdot 34 \times 10^{9}\right.$ daltons) is able to grow photoheterotrophically at the expense of glucose (Rippka et al., 1979). The members of sub-group 2 ( 47 to $56 \mathrm{~mol} \% \mathrm{GC}$ ) fall into two further groups with respect to genome size. In the first, seven strains, which show marked phenotypic diversity, possess genomes of similar sizes $\left(1.57 \times 10^{9}\right.$ to $2.12 \times 10^{9}$ daltons, mean $1.81 \times 10^{9}$ daltons $)$; three members of this group $(6311,6301$ and 6908) appear to be closely related (Rippka et al., 1979) and vary in genome size from $1.57 \times 10^{9}$ to $2.12 \times 10^{9}$ daltons. Strain 6910 contains a slightly larger genome $\left(2.52 \times 10^{9}\right.$ daltons), and is the only Synechococcus strain in which gliding motility has been observed (Stanier et al., 1971). The second group contains two strains, 7425 and 7335 , which have larger genomes of $3.09 \times 10^{9}$ and $3.11 \times 10^{9}$ daltons, respectively; although these strains differ from each other in many phenotypic properties they are both distinguished from all other members of sub-group 2 by their ability to fix 
Table 1. Genome sizes of cyanobacteria assigned to Section I

\begin{tabular}{|c|c|c|c|c|c|}
\hline \multirow[b]{2}{*}{ Genus } & \multicolumn{2}{|c|}{ Strain number } & \multirow[b]{2}{*}{$\mathrm{N}^{*}$} & \multirow{2}{*}{$\begin{array}{c}k_{2} \\
\left(\mathrm{l} \mathrm{mol} \mathrm{mol}^{-1} \mathrm{~s}^{-1}\right) \\
\pm \text { S.D. } \dagger\end{array}$} & \multirow{2}{*}{$\begin{array}{c}10^{-9} \times \\
\text { Genome size } \\
\text { (daltons) } \\
\pm \text { S.D. }\end{array}$} \\
\hline & PCC & ATCC & & & \\
\hline $\begin{array}{l}\text { Synechococcus } \\
\text { Sub-group } 1\end{array}$ & $\begin{array}{l}7502 \\
7202 \\
7418 \\
7511 \\
7424\end{array}$ & $\begin{array}{l}29172 \\
29140 \\
29534 \\
29154 \\
29155\end{array}$ & $\begin{array}{l}3 \\
3 \\
3 \\
4 \\
4\end{array}$ & $\begin{array}{l}3 \cdot 74 \pm 0.06 \\
3.60 \pm 0.08 \\
3 \cdot 09 \pm 0.07 \\
2 \cdot 85 \pm 0.06 \\
2 \cdot 27 \pm 0.18\end{array}$ & $\begin{array}{l}2.55 \pm 0.04 \\
2.65 \pm 0.06 \\
3.08 \pm 0.07 \\
3.34 \pm 0.07 \\
4.20 \pm 0.33\end{array}$ \\
\hline Sub-group 2 & $\begin{array}{l}\left\{\begin{array}{l}6311 \\
6908 \\
6301\end{array}\right. \\
7002 \\
6716 \\
7003 \\
6312 \\
6910\end{array}$ & $\begin{array}{l}27145 \\
27146 \\
27144 \\
27264 \\
27179 \\
27265 \\
27167 \\
27191\end{array}$ & $\begin{array}{l}4 \\
3 \\
9 \\
6 \\
3 \\
5 \\
3 \\
6\end{array}$ & $\begin{array}{l}6 \cdot 07 \pm 0.31 \\
5 \cdot 74 \pm 0.10 \\
4.50 \pm 0.32 \\
5 \cdot 67 \pm 0.41 \\
5 \cdot 54 \pm 0.19 \\
4.86 \pm 0.27 \\
4.81 \pm 0.05 \\
3 \cdot 78 \pm 0.38\end{array}$ & $\begin{array}{l}1.57 \pm 0.08 \\
1.66 \pm 0.03 \\
2.12 \pm 0.15 \\
1.68 \pm 0.12 \\
1.72 \pm 0.06 \\
1.96 \pm 0.11 \\
1.98 \pm 0.02 \\
2.52 \pm 0.25\end{array}$ \\
\hline & $\begin{array}{l}7425 \\
7335\end{array}$ & $\begin{array}{l}29141 \\
29403\end{array}$ & $\begin{array}{l}3 \\
3\end{array}$ & $\begin{array}{l}3.08 \pm 0.04 \\
3.06 \pm 0.07\end{array}$ & $\begin{array}{l}3.09 \pm 0.04 \\
3.11 \pm 0.07\end{array}$ \\
\hline Sub-group 3 & $\begin{array}{r}7001 \\
\left\{\begin{array}{l}6603 \\
6710 \\
6307\end{array}\right. \\
7009\end{array}$ & $\begin{array}{l}27194 \\
27168 \\
27174 \\
27147 \\
29203\end{array}$ & $\begin{array}{l}3 \\
3 \\
5 \\
3 \\
3\end{array}$ & $\begin{array}{l}4 \cdot 74 \pm 0 \cdot 31 \\
4 \cdot 47 \pm 0 \cdot 06 \\
4 \cdot 31 \pm 0 \cdot 23 \\
3 \cdot 72 \pm 0 \cdot 39 \\
3 \cdot 91 \pm 0 \cdot 05\end{array}$ & $\begin{array}{l}2 \cdot 01 \pm 0 \cdot 13 \\
2 \cdot 13 \pm 0.03 \\
2 \cdot 21 \pm 0 \cdot 12 \\
2 \cdot 56 \pm 0.27 \\
2 \cdot 44 \pm 0.03\end{array}$ \\
\hline $\begin{array}{l}\text { Synechocystis } \\
\text { Sub-group } 1\end{array}$ & $\begin{array}{l}6808 \\
6711 \\
6804 \\
6701\end{array}$ & $\begin{array}{l}27189 \\
27175 \\
27185 \\
27170\end{array}$ & $\begin{array}{l}4 \\
3 \\
5 \\
9\end{array}$ & $\begin{array}{l}4 \cdot 50 \pm 0 \cdot 13 \\
4 \cdot 43 \pm 0 \cdot 21 \\
3 \cdot 95 \pm 0 \cdot 13 \\
3 \cdot 81 \pm 0 \cdot 14\end{array}$ & $\begin{array}{l}2 \cdot 12 \pm 0.06 \\
2 \cdot 15 \pm 0 \cdot 10 \\
2 \cdot 41 \pm 0.08 \\
2 \cdot 50 \pm 0.09\end{array}$ \\
\hline Sub-group 2 & 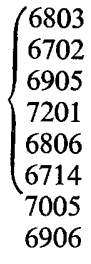 & $\begin{array}{l}27184 \\
27171 \\
29109 \\
29152 \\
27187 \\
27178 \\
27153 \\
27266\end{array}$ & $\begin{array}{l}8 \\
4 \\
4 \\
3 \\
4 \\
3 \\
3 \\
3\end{array}$ & $\begin{array}{l}5 \cdot 32 \pm 0 \cdot 15 \\
4 \cdot 65 \pm 0 \cdot 36 \\
4 \cdot 58 \pm 0 \cdot 29 \\
4 \cdot 33 \pm 0 \cdot 18 \\
4 \cdot 13 \pm 0 \cdot 16 \\
4 \cdot 07 \pm 0 \cdot 14 \\
4 \cdot 63 \pm 0 \cdot 16 \\
4 \cdot 06 \pm 0 \cdot 17\end{array}$ & $\begin{array}{l}1.79 \pm 0.05 \\
2.05 \pm 0.16 \\
2.08 \pm 0.13 \\
2 \cdot 20 \pm 0.09 \\
2 \cdot 31 \pm 0.09 \\
2 \cdot 34 \pm 0.08 \\
2.06 \pm 0.07 \\
2.35 \pm 0.10\end{array}$ \\
\hline & 7509 & 29235 & 3 & $2 \cdot 73 \pm 0.31$ & $3 \cdot 50 \pm 0 \cdot 23$ \\
\hline Gloeobacter & 7421 & 29082 & 3 & $3 \cdot 54 \pm 0 \cdot 24$ & $2 \cdot 69 \pm 0 \cdot 18$ \\
\hline Gloeocapsa & $\begin{array}{r}7512 \\
73106 \\
7501 \\
7428\end{array}$ & $\begin{array}{l}29115 \\
27928 \\
29113 \\
29159\end{array}$ & $\begin{array}{l}3 \\
3 \\
3 \\
3\end{array}$ & $\begin{array}{l}3 \cdot 29 \pm 0.07 \\
3 \cdot 21 \pm 0 \cdot 31 \\
2 \cdot 77 \pm 0 \cdot 16 \\
2 \cdot 75 \pm 0.13\end{array}$ & $\begin{array}{l}2.90 \pm 0.06 \\
2.97 \pm 0.29 \\
3.44 \pm 0.20 \\
3.47 \pm 0.16\end{array}$ \\
\hline Gloeothece & $\begin{array}{r}73108 \\
7109\end{array}$ & $\begin{array}{l}29164 \\
29163\end{array}$ & $\begin{array}{l}3 \\
3\end{array}$ & $\begin{array}{l}1.90 \pm 0.04 \\
1.83 \pm 0.05\end{array}$ & $\begin{array}{l}5 \cdot 02 \pm 0 \cdot 10 \\
5 \cdot 22 \pm 0 \cdot 15\end{array}$ \\
\hline Chamaesiphon & $\begin{array}{l}7430 \\
6605\end{array}$ & $\begin{array}{l}29397 \\
27169\end{array}$ & $\begin{array}{l}3 \\
4\end{array}$ & $\begin{array}{l}2.62 \pm 0.07 \\
2.54 \pm 0.19\end{array}$ & $\begin{array}{l}3.64 \pm 0.10 \\
3.75 \pm 0.39\end{array}$ \\
\hline
\end{tabular}

* Number of determinations. $\uparrow$ Standard deviation. 
nitrogen under anaerobic conditions (Rippka \& Waterbury, 1977). The five members of subgroup 3 (66 to $71 \mathrm{~mol} \% \mathrm{GC}$ ) have genomes of similar sizes $\left(2.01 \times 10^{9}\right.$ to $2.56 \times 10^{9}$ daltons) with a mean of $2 \cdot 27 \times 10^{9}$ daltons. Three of these strains $(6603,6710$ and 6307$)$ appear to be closely related (Rippka et al., 1979) and vary in genome size from $2.13 \times 10^{9}$ to $2.56 \times 10^{9}$ daltons.

Although the members of the genus Synechocystis (sheathless unicellular cyanobacteria which divide successively in two or three different planes) fall into two groups of different base composition (Herdman et al., 1979), the majority of the strains possess genomes of similar size. The members of sub-group 1 ( 35 to $37 \mathrm{~mol} \% \mathrm{GC}$ ) display several phenotypes but a narrow range of genome size $\left(2.12 \times 10^{9}\right.$ to $2.50 \times 10^{9}$ daltons, mean $2.30 \times 10^{9}$ daltons). In sub-group 2 (42 to $48 \mathrm{~mol} \% \mathrm{GC})$ eight of the strains occupy a similar range $\left(1.79 \times 10^{9}\right.$ to $2.35 \times 10^{9}$ daltons) with a mean of $2.15 \times 10^{9}$ daltons, six of them being closely related (Rippka et al., 1979). The remaining strain of sub-group 2, 7509, has a larger genome of $3.50 \times 10^{9}$ daltons and is further distinguished by its ability to grow photoheterotrophically at the expense of sucrose (Rippka et al., 1979).

The other genera of Section I are each represented by a limited number of isolates. The genus Gloeobacter (ensheathed unicellular cyanobacteria, lacking thylakoids, which divide in one plane) contains only one strain, which possesses a genome of $2.69 \times 10^{9}$ daltons. Gloeocapsa (ensheathed unicellular cyanobacteria dividing successively in three different planes $)$ is represented by four strains which differ both in genome size $\left(2.90 \times 10^{9}\right.$ to $3.47 \times$ $10^{9}$ daltons, mean $3.20 \times 10^{9}$ daltons) and in other properties (Rippka et al., 1979). The two strains of Gloeothece (ensheathed unicellular cyanobacteria which divide in a single plane) possess the largest genomes $\left(5.02 \times 10^{9}\right.$ and $5.22 \times 10^{9}$ daltons $)$ of any unicellular prokaryote so far investigated. These strains also differ from all other unicellular cyanobacteria in their capacity to fix nitrogen under aerobic conditions (Rippka \& Waterbury, 1977). The two members of the genus Chamaesiphon are distinguished from all other unicellular cyanobacteria by their mode of reproduction (bud formation). Although these strains differ from each other in many properties (Waterbury \& Stanier, 1977), their genomes are similar both in base composition (Herdman et al., 1979) and size $\left(3.64 \times 10^{9}\right.$ and $3.75 \times 10^{9}$ daltons).

The distribution of genome sizes of all unicellular cyanobacteria of Section I is shown in Fig. 1(a). With the exception of the genus Gloeothece, the overall range $\left(1.6 \times 10^{9}\right.$ to $4 \cdot 2 \times$ $10^{9}$ daltons) is similar to that of other bacteria (Gillis et al., 1970; Wallace \& Morowitz, 1973).

\section{Genome sizes of cyanobacteria assigned to Section II}

The members of Section II (pleurocapsalean strains) reproduce by the release of small baeocytes (Waterbury \& Stanier, 1978) which arise by multiple fission within a larger vegetative cell. Full descriptions of the strain properties are given by Waterbury \& Stanier (1978). The genome sizes of the members of this section are shown in Table 2.

The genus Chroococcidiopsis is divided into two groups of different DNA base composition (Herdman et al., 1979) which, from the study of a limited number of strains, also differ in genome size. Strain $6712\left(40 \mathrm{~mol} \%\right.$ GC) contains a genome of $3.31 \times 10^{9}$ daltons; the remaining three strains (46 mol \% GC) possess larger genomes $\left(4.06 \times 10^{9}\right.$ to $4.75 \times 10^{9}$ daltons, mean $4.48 \times 10^{9}$ daltons). The other genera of Section II (Dermocarpa, Dermocarpella, Xenococcus, Myxosarcina and the Pleurocapsa group) vary in genome size from $3.07 \times 10^{9}$ to $4.39 \times 10^{9}$ daltons; since few members of these genera have been examined the intrageneric variation in genome size remains unknown.

In spite of the wide variation in morphological and physiological properties in the members of Section II (Waterbury \& Stanier, 1978), the 11 strains examined exhibit a narrow range of DNA base composition (Herdman et al., 1979) and genome size (Fig. 1b); the genome sizes are clustered around the upper limit of the range of other bacteria, with a mean of $3.78 \times 10^{9}$ daltons. 


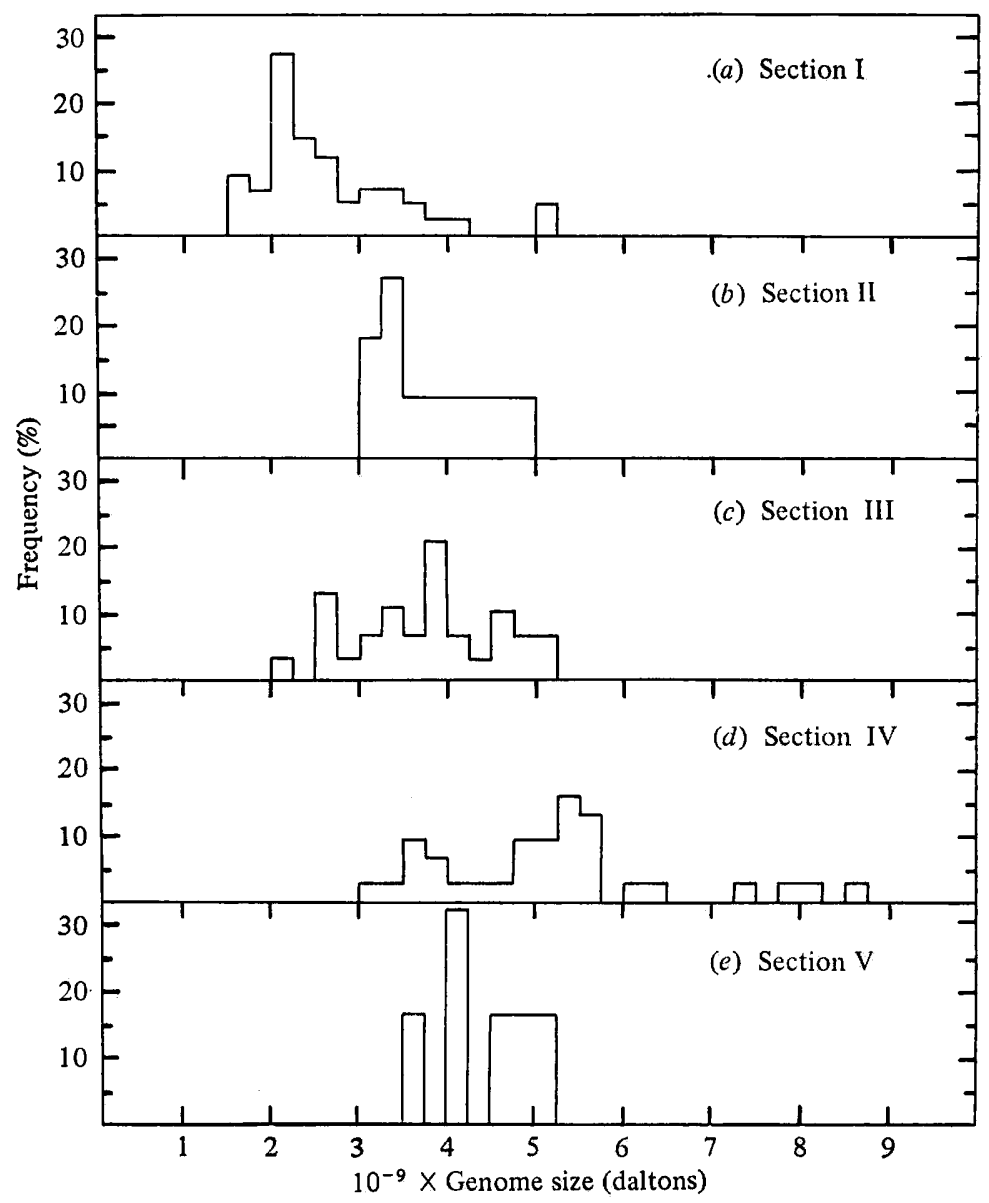

Fig. 1. The distribution of the genome sizes of cyanobacteria assigned to Sections I to V.

Table 2. Genome sizes of cyanobacteria assigned to Section II

\begin{tabular}{|c|c|c|c|c|c|}
\hline \multirow[b]{2}{*}{ Genus } & \multicolumn{2}{|c|}{ Strain number } & \multirow[b]{2}{*}{$\mathbf{N}$} & \multirow{2}{*}{$\begin{array}{c}k_{2} \\
\left(1 \mathrm{~mol}^{-1} \mathrm{~s}^{-1}\right) \\
\pm \text { s.D. }\end{array}$} & \multirow{2}{*}{$\begin{array}{c}10^{-9} \times \\
\text { Genome size } \\
\text { (daltons) } \\
\pm \text { S.D. }\end{array}$} \\
\hline & PCC & ATCC & & & \\
\hline Dermocarpa & $\begin{array}{l}7301 \\
7438\end{array}$ & $\begin{array}{l}29367 \\
29372\end{array}$ & $\begin{array}{l}3 \\
4\end{array}$ & $\begin{array}{l}3 \cdot 10 \pm 0.06 \\
2 \cdot 17 \pm 0.09\end{array}$ & $\begin{array}{l}3.07 \pm 0.05 \\
4.39 \pm 0.19\end{array}$ \\
\hline Xenococcus & 7307 & 29375 & 3 & $2.39 \pm 0.06$ & $3 \cdot 99 \pm 0 \cdot 13$ \\
\hline Dermocarpella & 7326 & 29376 & 3 & $2 \cdot 86 \pm 0.06$ & $3 \cdot 33 \pm 0 \cdot 07$ \\
\hline Myxosarcina & 7312 & 29377 & 3 & $2 \cdot 70 \pm 0 \cdot 08$ & $3 \cdot 53 \pm 0 \cdot 10$ \\
\hline $\begin{array}{c}\text { Chroococcidiopsis } \\
\text { Sub-group } 1\end{array}$ & 6712 & 27176 & 4 & $2 \cdot 88 \pm 0 \cdot 10$ & $3 \cdot 31 \pm 0 \cdot 11$ \\
\hline Sub-group 2 & $\begin{array}{r}\left\{\begin{array}{l}7203 \\
7433 \\
7434\end{array}\right.\end{array}$ & $\begin{array}{l}27900 \\
29381 \\
29382\end{array}$ & $\begin{array}{l}3 \\
3 \\
3\end{array}$ & $\begin{array}{l}2 \cdot 35 \pm 0.15 \\
2 \cdot 01 \pm 0.05 \\
2 \cdot 06 \pm 0.07\end{array}$ & $\begin{array}{l}4 \cdot 06 \pm 0 \cdot 26 \\
4 \cdot 75 \pm 0 \cdot 12 \\
4 \cdot 62 \pm 0 \cdot 15\end{array}$ \\
\hline Pleurocapsa group & $\begin{array}{l}7322 \\
7320\end{array}$ & $\begin{array}{l}29391 \\
29389\end{array}$ & $\begin{array}{l}3 \\
3\end{array}$ & $\begin{array}{l}3.04 \pm 0.08 \\
2 \cdot 78 \pm 0.07\end{array}$ & $\begin{array}{l}3 \cdot 13 \pm 0.08 \\
3 \cdot 43 \pm 0.09\end{array}$ \\
\hline
\end{tabular}




\section{Genome sizes of cyanobacteria assigned to Section III}

Section III (Table 3) contains filamentous cyanobacteria which do not produce heterocysts. The overall range of genome size $\left(2 \cdot 14 \times 10^{9}\right.$ to $5 \cdot 19 \times 10^{9}$ daltons $)$ is similar to that of Section I, although the distribution of sizes (Fig. 1c) is different.

The single strain of the genus Spirulina (filamentous cyanobacteria that produce motile, helical trichomes) examined differs from the majority of the members of Section III in possessing a small genome of $2.53 \times 10^{9}$ daltons.

The genomes of the six strains of Oscillatoria (filamentous cyanobacteria that produce motile, sheathless or thinly ensheathed trichomes composed of disc-shaped cells) vary from $2.50 \times 10^{9}$ to $4.38 \times 10^{9}$ daltons (mean $3.62 \times 10^{9}$ daltons). The recent isolate of Oscillatoria agardhii (PCC 7805) is distinguished from all other Oscillatoria strains by the abundance and irregular distribution of gas vacuoles and contains the smallest genome $\left(2.50 \times 10^{9}\right.$ daltons) of the strains examined in this group. Three strains, which differ from one another in many properties but share the ability to fix nitrogen under anaerobic conditions (Rippka et al., 1979), possess larger genomes $\left(3.15 \times 10^{9}\right.$ to $3.86 \times 10^{9}$ daltons). The remaining two strains, genome sizes $4.20 \times 10^{9}$ and $4.38 \times 10^{9}$ daltons, seem to be closely related in other respects; they are both obligate autotrophs, incapable of fixing nitrogen under anaerobic conditions (Rippka et al., 1979).

The seven members of the genus Pseudanabaena (filamentous cyanobacteria that produce motile, sheathless trichomes composed of cylindrical cells which contain polar gas vacuoles) exhibit a range of genome size from $2.14 \times 10^{9}$ to $3.77 \times 10^{9}$ (mean $3.05 \times 10^{9}$ ) daltons. Although many of these strains contain genomes of similar size, they differ extensively from each other in their phenotypic properties (Rippka et al., 1979). Strain 6901 contains the smallest genome of all filamentous cyanobacteria.

The LPP group is a provisional category containing a large number of strains for which generic assignments have not yet been made; the taxonomic difficulties are discussed by Rippka et al. (1979). The 24 strains can be divided into three distinct sub-groups of different genome size. The first contains two strains of genome size $2.58 \times 10^{9}$ and $2.63 \times 10^{9}$ daltons. The genomes of the 12 strains of the second sub-group vary from $3.16 \times 10^{9}$ to $4.08 \times 10^{9}$ daltons (mean $3.72 \times 10^{9}$ daltons) and the third sub-group contains 10 strains with genomes of $4.53 \times 10^{9}$ to $5.19 \times 10^{9}$ daltons (mean $4.86 \times 10^{9}$ daltons). The members of each of these sub-groups are highly diverse phenotypically (Rippka et al., 1979) and in mean DNA base composition (Herdman et al., 1979). Although five strains of the LPP group are indistinguishable by all other phenotypic characters examined (Rippka et al., 1979) they fall into two different genome size groups; one contains strains 7505 and $6402\left(3.86 \times 10^{9}\right.$ and $3.99 \times$ $10^{9}$ daltons, respectively) and the other 6306,7410 and $73110\left(4.78 \times 10^{9}\right.$ to $5.15 \times 10^{9}$ daltons). Two members of the latter group, 6306 and 73110 , have been shown by DNA hybridization studies to share $98 \%$ homology (Stam \& Venema, 1977: the strains were identified as UTEX 581 and 594 respectively).

\section{Genome sizes of cyanobacteria assigned to Section IV}

Section IV (Table 4) contains heterocystous cyanobacteria whose cells divide in a single plane to produce unbranched filaments. The genera of this section have been placed into two groups based on their ability to form hormogonia (Rippka et al., 1979). Section IVa contains three genera (Anabaena, Nodularia and Cylindrospermum) which do not produce hormogonia; Section IVb contains the hormogonia-producing genera Nostoc, Calothrix and Scytonema.

The six strains of the genus Anabaena, which possess trichomes composed of spherical, ovoid or cylindrical vegetative cells and containing both intercalary and terminal heterocysts, vary in genome size from $3 \cdot 17 \times 10^{9}$ to $3 \cdot 89 \times 10^{9}$ daltons. They have been divided into 
Table 3. Genome sizes of cyanobacteria assigned to Section III

\begin{tabular}{|c|c|c|c|c|c|}
\hline \multirow[b]{2}{*}{ Genus } & \multicolumn{2}{|c|}{ Strain number } & \multirow[b]{2}{*}{$\mathbf{N}$} & \multirow{2}{*}{$\begin{array}{c}k_{2} \\
\left(\mathrm{I} \mathrm{mol}^{-1} \mathrm{~s}^{-1}\right) \\
\text { 土S.D. }\end{array}$} & \multirow{2}{*}{$\begin{array}{c}10^{-9} \times \\
\text { Genome size } \\
\text { (daltons) } \\
\pm \text { S.D. }\end{array}$} \\
\hline & PCC & ATCC & & & \\
\hline Oscillatoria & $\begin{array}{r}7805 \\
6412 \\
7515 \\
6602 \\
\left\{\begin{array}{l}7412 \\
6304\end{array}\right.\end{array}$ & $\begin{array}{c}- \\
29205 \\
29209 \\
27935 \\
29135 \\
27930\end{array}$ & $\begin{array}{l}3 \\
3 \\
3 \\
3 \\
3 \\
3\end{array}$ & $\begin{array}{l}3.81 \pm 0.07 \\
3.03 \pm 0.06 \\
2.62 \pm 0.06 \\
2.47 \pm 0.07 \\
2.27 \pm 0.05 \\
2.18 \pm 0.09\end{array}$ & $\begin{array}{l}2.50 \pm 0.05 \\
3.15 \pm 0.06 \\
3.63 \pm 0.08 \\
3.86 \pm 0.11 \\
4.20 \pm 0.09 \\
4.38 \pm 0.19\end{array}$ \\
\hline Pseudanabaena & $\begin{array}{l}6901 \\
7402 \\
7367 \\
7403 \\
7429 \\
6802 \\
6406\end{array}$ & $\begin{array}{l}27263 \\
29207 \\
29137 \\
29210 \\
29536 \\
27183 \\
29118\end{array}$ & $\begin{array}{l}5 \\
3 \\
3 \\
3 \\
3 \\
3 \\
3\end{array}$ & $\begin{array}{l}4 \cdot 45 \pm 0.21 \\
3 \cdot 80 \pm 0 \cdot 15 \\
3 \cdot 23 \pm 0.07 \\
3 \cdot 01 \pm 0 \cdot 10 \\
2 \cdot 82 \pm 0.08 \\
2 \cdot 78 \pm 0.22 \\
2 \cdot 53 \pm 0.20\end{array}$ & $\begin{array}{l}2 \cdot 14 \pm 0 \cdot 10 \\
2 \cdot 51 \pm 0 \cdot 10 \\
2 \cdot 95 \pm 0 \cdot 06 \\
3 \cdot 17 \pm 0 \cdot 11 \\
3 \cdot 38 \pm 0 \cdot 10 \\
3 \cdot 43 \pm 0 \cdot 28 \\
3 \cdot 77 \pm 0 \cdot 30\end{array}$ \\
\hline Spirulina & 6313 & 29542 & 3 & $3 \cdot 77 \pm 0.06$ & $2 \cdot 53 \pm 0.04$ \\
\hline LPP group & $\begin{array}{l}7407 \\
7376\end{array}$ & $\begin{array}{l}29126 \\
29410\end{array}$ & $\begin{array}{l}1 \\
3\end{array}$ & $\begin{array}{l}3.70 \\
3.62 \pm 0.08\end{array}$ & $\begin{array}{l}2.58 \\
2.63 \pm 0.06\end{array}$ \\
\hline & $\begin{array}{l}7123 \\
6409 \\
7105 \\
7406 \\
6703 \\
7427 \\
7505 \\
7411 \\
7124 \\
7375 \\
6402 \\
7420\end{array}$ & $\begin{array}{l}29122 \\
29119 \\
29120 \\
29125 \\
27907 \\
29129 \\
29170 \\
29127 \\
29123 \\
29409 \\
27902 \\
29128\end{array}$ & $\begin{array}{l}3 \\
1 \\
3 \\
3 \\
3 \\
3 \\
3 \\
3 \\
3 \\
3 \\
3 \\
4\end{array}$ & $\begin{array}{l}3.02 \pm 0.17 \\
2 \cdot 85 \\
2 \cdot 81 \pm 0.05 \\
2.69 \pm 0.10 \\
2.65 \pm 0.05 \\
2.48 \pm 0.11 \\
2.47 \pm 0.07 \\
2.43 \pm 0.07 \\
2.42 \pm 0.05 \\
2.42 \pm 0.04 \\
2.39 \pm 0.07 \\
2.34 \pm 0.04\end{array}$ & $\begin{array}{l}3 \cdot 16 \pm 0 \cdot 18 \\
3 \cdot 34 \\
3 \cdot 39 \pm 0.06 \\
3 \cdot 54 \pm 0.13 \\
3.60 \pm 0.07 \\
3.85 \pm 0.17 \\
3.86 \pm 0 \cdot 10 \\
3.92 \pm 0.11 \\
3.93 \pm 0.08 \\
3.93 \pm 0.06 \\
3.99 \pm 0.11 \\
4.08 \pm 0.07\end{array}$ \\
\hline & 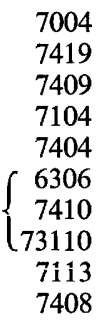 & $\begin{array}{l}27913 \\
29346 \\
29541 \\
29117 \\
29165 \\
27894 \\
29136 \\
29407 \\
29206 \\
29344\end{array}$ & $\begin{array}{l}3 \\
3 \\
4 \\
3 \\
3 \\
3 \\
3 \\
3 \\
4 \\
1 \\
4\end{array}$ & $\begin{array}{l}2 \cdot 10 \pm 0.13 \\
2.08 \pm 0.07 \\
2.06 \pm 0.12 \\
2.05 \pm 0.04 \\
1.92 \pm 0.06 \\
1.99 \pm 0.08 \\
1.91 \pm 0.05 \\
1.85 \pm 0.04 \\
1.87 \\
1.84 \pm 0.03\end{array}$ & $\begin{array}{l}4 \cdot 53 \pm 0 \cdot 29 \\
4 \cdot 58 \pm 0 \cdot 16 \\
4 \cdot 63 \pm 0 \cdot 27 \\
4 \cdot 65 \pm 0 \cdot 09 \\
4 \cdot 96 \pm 0 \cdot 15 \\
4 \cdot 78 \pm 0 \cdot 20 \\
4 \cdot 98 \pm 0 \cdot 13 \\
5 \cdot 15 \pm 0 \cdot 12 \\
5 \cdot 10 \\
5 \cdot 19 \pm 0.09\end{array}$ \\
\hline
\end{tabular}

two groups (indicated by braces in Table 4) of different phenotypic properties (Rippka et al., 1979). The single representative of the genus Nodularia, which differs from Anabaena primarily in cell shape (Rippka et al., 1979), contains a genome of $3.34 \times 10^{9}$ daltons. Cylindrospermum, which produces only terminal heterocysts and sub-terminal akinetes, is represented by two phenotypically similar strains which contain genomes of $5.71 \times 10^{9}$ and $6.15 \times 10^{9}$ daltons. The genome sizes of Anabaena and Nodularia strains therefore fall within the normal range of bacterial genome size and are significantly smaller than those of Cylindrospermum and the members of Section IVb described below.

The 11 Nostoc strains, which differ from Anabaena primarily in their ability to produce hormogonia, exhibit a wide range of genome size $\left(4.00 \times 10^{9}\right.$ to $6.42 \times 10^{9}$ daltons, mean $5.09 \times 10^{9}$ daltons). Similarity of genome size, however, does not imply close relatedness since many strains of similar genome size differ markedly in other phenotypic properties (see Rippka et al., 1979). The members of the genus Calothrix possess tapering trichomes with a terminal heterocyst at only one end; growth results both in elongation of the trichome 
Table 4. Genome sizes of cyanobacteria assigned to Section IV

\begin{tabular}{|c|c|c|c|c|c|}
\hline \multirow[b]{2}{*}{ Genus } & \multicolumn{2}{|c|}{ Strain number } & \multirow[b]{2}{*}{$N$} & \multirow{2}{*}{$\begin{array}{c}k_{2} \\
\left(\mathrm{l} \mathrm{mol}^{-1} \mathrm{~s}^{-1}\right) \\
\pm \text { S.D. }\end{array}$} & \multirow{2}{*}{$\begin{array}{l}10^{-9} \times \\
\text { Genome size } \\
\text { (daitons) } \\
\text { 土S.D. }\end{array}$} \\
\hline & PCC & ATCC & & & \\
\hline Anabaena & $\begin{array}{l}\left\{\begin{array}{l}7122 \\
6309\end{array}\right. \\
\left\{\begin{array}{l}7120 \\
7118 \\
7119 \\
6411\end{array}\right.\end{array}$ & $\begin{array}{l}27899 \\
29211 \\
27893 \\
27892 \\
29151 \\
27898\end{array}$ & $\begin{array}{l}3 \\
3 \\
3 \\
3 \\
3 \\
4\end{array}$ & $\begin{array}{l}3.01 \pm 0.17 \\
2.68 \pm 0.17 \\
2.55 \pm 0.07 \\
2.55 \pm 0.05 \\
2.47 \pm 0.06 \\
2.45 \pm 0.14\end{array}$ & $\begin{array}{l}3 \cdot 17 \pm 0.18 \\
3 \cdot 56 \pm 0.22 \\
3 \cdot 74 \pm 0 \cdot 10 \\
3 \cdot 74 \pm 0.08 \\
3 \cdot 86 \pm 0.09 \\
3 \cdot 89 \pm 0.22\end{array}$ \\
\hline Nodularia & 73104 & 29167 & 3 & $2 \cdot 85 \pm 0 \cdot 15$ & $3 \cdot 34 \pm 0 \cdot 17$ \\
\hline Cylindrospermum & $\begin{array}{r}73101 \\
7417\end{array}$ & $\begin{array}{l}29535 \\
29204\end{array}$ & $\begin{array}{l}3 \\
3\end{array}$ & $\begin{array}{l}1.67 \pm 0.09 \\
1.55 \pm 0.08\end{array}$ & $\begin{array}{l}5 \cdot 71 \pm 0 \cdot 32 \\
6 \cdot 15 \pm 0.47\end{array}$ \\
\hline Nostoc & $\begin{array}{r}6719 \\
7413 \\
6310 \\
7416 \\
73102 \\
7423 \\
6314 \\
6705 \\
7524 \\
6302 \\
7422\end{array}$ & $\begin{array}{l}29105 \\
29106 \\
27896 \\
29107 \\
29133 \\
29168 \\
27904 \\
29131 \\
29411 \\
27897 \\
29132\end{array}$ & $\begin{array}{l}4 \\
3 \\
3 \\
3 \\
4 \\
3 \\
3 \\
3 \\
4 \\
3 \\
3\end{array}$ & $\begin{array}{l}2.38 \pm 0.09 \\
2.14 \pm 0.06 \\
2.11 \pm 0.04 \\
1.99 \pm 0.09 \\
1.95 \pm 0.16 \\
1.94 \pm 0.07 \\
1.86 \pm 0.04 \\
1.72 \pm 0.15 \\
1.70 \pm 0.11 \\
1.67 \pm 0.09 \\
1.48 \pm 0.09\end{array}$ & $\begin{array}{l}4 \cdot 00 \pm 0 \cdot 15 \\
4 \cdot 46 \pm 0 \cdot 12 \\
4 \cdot 52 \pm 0.09 \\
4 \cdot 78 \pm 0 \cdot 22 \\
4 \cdot 89 \pm 0 \cdot 39 \\
4.91 \pm 0 \cdot 18 \\
5 \cdot 12 \pm 0 \cdot 12 \\
5 \cdot 55 \pm 0.48 \\
5 \cdot 61 \pm 0 \cdot 36 \\
5 \cdot 71 \pm 0 \cdot 32 \\
6.42 \pm 0.39\end{array}$ \\
\hline Calothrix & $\begin{array}{l}6303 \\
7103 \\
7204 \\
7111 \\
7415 \\
7116 \\
7507\end{array}$ & $\begin{array}{l}29156 \\
27905 \\
29190 \\
29199 \\
29157 \\
29111 \\
29112\end{array}$ & $\begin{array}{l}3 \\
3 \\
3 \\
3 \\
3 \\
3 \\
3 \\
3\end{array}$ & $\begin{array}{l}1.88 \pm 0.07 \\
1.82 \pm 0.07 \\
1.81 \pm 0.04 \\
1.78 \pm 0.13 \\
1.78 \pm 0.10 \\
1.76 \pm 0.07 \\
1.75 \pm 0.09\end{array}$ & $\begin{array}{l}5 \cdot 07 \pm 0 \cdot 19 \\
5 \cdot 23 \pm 0 \cdot 21 \\
5 \cdot 26 \pm 0 \cdot 13 \\
5 \cdot 35 \pm 0 \cdot 40 \\
5 \cdot 35 \pm 0 \cdot 32 \\
5 \cdot 41 \pm 0 \cdot 22 \\
5 \cdot 46 \pm 0 \cdot 28\end{array}$ \\
\hline & $\begin{array}{l}7101 \\
7426 \\
7102\end{array}$ & $\begin{array}{l}27914 \\
29345 \\
27901\end{array}$ & $\begin{array}{l}3 \\
3 \\
3\end{array}$ & $\begin{array}{l}1.23 \pm 0.03 \\
1.17 \pm 0.07 \\
1.11 \pm 0.07\end{array}$ & $\begin{array}{l}7.75 \pm 0.18 \\
8 \cdot 15 \pm 0.49 \\
8.58 \pm 0.55\end{array}$ \\
\hline Scytonema & 7110 & 29171 & 4 & $1.29 \pm 0.06$ & $7 \cdot 40 \pm 0 \cdot 36$ \\
\hline
\end{tabular}

and in increased diameter of the basal vegetative cells, and is accompanied by the differentiation of new, larger heterocysts from the sub-terminal cell. The members of this genus therefore display an organization totally different from that of any other filamentous heterocystous cyanobacteria. The 10 strains examined fall into two groups on the basis of genome size; the first contains seven strains with genomes of $5.07 \times 10^{9}$ to $5 \cdot 46 \times 10^{9}$ daltons (mean $5.30 \times 10^{9}$ daltons), and the second contains three strains with larger genomes $\left(7.75 \times 10^{9}\right.$ to $8.58 \times 10^{9}$ daltons, mean $8.16 \times 10^{9}$ daltons). The sub-division of the genus in this way is not consistent with any other known phenotypic properties (Rippka et al., 1979) of its strains. The single representative of the genus Scytonema resembles the Calothrix strains in producing hormogonia which develop a single terminal heterocyst; subsequent growth, however, produces a trichome of uniform width which, unlike Calothrix, contains intercalary heterocysts. The genome size of $7.40 \times 10^{9}$ daltons is close to those of the second sub-group of Calothrix.

The members of Section IV (Fig. 1d) therefore show a wider variation in genome size $\left(3.17 \times 10^{9}\right.$ to $8.58 \times 10^{9}$ daltons) than any other section. This variation is accompanied by extensive variation in morphological complexity (see Figs 33 to 69 of Rippka et al., 1979) and in physiological properties. The members of the second Calothrix group, together with the single Scytonema strain, possess the largest genomes of all prokaryotes so far examined. 
Table 5. Genome sizes of cyanobacteria assigned to Section $V$

\begin{tabular}{|c|c|c|c|c|c|}
\hline \multirow[b]{2}{*}{ Genus } & \multicolumn{2}{|c|}{ Strain number } & \multirow[b]{2}{*}{$\mathbf{N}$} & \multirow{2}{*}{$\begin{array}{c}k_{2} \\
\left(1 \mathrm{~mol}^{-1} \mathrm{~s}^{-1}\right) \\
\pm \text { S.D. }\end{array}$} & \multirow{2}{*}{$\begin{array}{l}10^{-9} \times \\
\text { Genome size } \\
\text { (daltons) } \\
\pm \text { s.D. }\end{array}$} \\
\hline & PCC & ATCC & & & \\
\hline Chlorogloeopsis & $\begin{array}{l}6912 \\
6718\end{array}$ & $\begin{array}{l}27193 \\
27181\end{array}$ & $\begin{array}{l}4 \\
3\end{array}$ & $\begin{array}{l}2 \cdot 27 \pm 0 \cdot 11 \\
1 \cdot 82 \pm 0 \cdot 12\end{array}$ & $\begin{array}{l}4 \cdot 20 \pm 0 \cdot 21 \\
5 \cdot 24 \pm 0.35\end{array}$ \\
\hline Fischerella & $\begin{array}{r}7521 \\
73103 \\
7115 \\
7414\end{array}$ & $\begin{array}{l}29538 \\
29114 \\
27929 \\
29161\end{array}$ & $\begin{array}{l}3 \\
3 \\
3 \\
3\end{array}$ & $\begin{array}{l}2 \cdot 63 \pm 0.07 \\
2 \cdot 37 \pm 0.07 \\
2 \cdot 09 \pm 0.12 \\
2 \cdot 01 \pm 0.08\end{array}$ & $\begin{array}{l}3 \cdot 62 \pm 0 \cdot 10 \\
4 \cdot 02 \pm 0 \cdot 12 \\
4 \cdot 55 \pm 0.26 \\
4 \cdot 75 \pm 0.19\end{array}$ \\
\hline
\end{tabular}

Table 6. Rapidly renaturing fractions in cyanobacterial DNA

\begin{tabular}{|c|c|c|c|c|c|c|}
\hline Section & Genus & $\begin{array}{l}\text { Strain } \\
\text { number } \\
\text { PCC }\end{array}$ & $\begin{array}{c}k_{2} \\
\left(1 \mathrm{~mol}^{-1} \mathrm{~s}^{-1}\right)\end{array}$ & $\begin{array}{c}10^{-6} \times \\
\text { Kinetic } \\
\text { complexity } \\
\text { (daltons) }\end{array}$ & $\begin{array}{l}\% \text { of } \\
\text { total } \\
\text { genome }\end{array}$ & $\begin{array}{l}\text { Copy } \\
\text { number }\end{array}$ \\
\hline I & Gloeothece & 73108 & 2464 & 3.9 & 5.9 & 76 \\
\hline I & Gloeocapsa & 73106 & 3876 & $2 \cdot 5$ & $5 \cdot 7$ & 67 \\
\hline$I$ & Synechocystis & $\begin{array}{l}6711 \\
6701 \\
7005\end{array}$ & $\begin{array}{l}5904 \\
1592 \\
1133\end{array}$ & $\begin{array}{l}1 \cdot 6 \\
6 \cdot 0 \\
8 \cdot 4\end{array}$ & $\begin{array}{r}4 \cdot 8 \\
9 \cdot 4 \\
10 \cdot 8\end{array}$ & $\begin{array}{l}64 \\
40 \\
26\end{array}$ \\
\hline II & Xenococcus & 7305 & 385 & $25^{*}$ & $20^{*}$ & $33^{*}$ \\
\hline III & Oscillatoria & 6412 & 833 & $11 \cdot 0$ & 11.5 & 32 \\
\hline III & LPP group & $\begin{array}{l}7406 \\
7375\end{array}$ & $\begin{array}{l}287 \\
273\end{array}$ & $\begin{array}{l}33 \cdot 2 \\
34 \cdot 9\end{array}$ & $\begin{array}{l}23 \cdot 3 \\
23 \cdot 6\end{array}$ & $\begin{array}{l}25 \\
24\end{array}$ \\
\hline IV & Anabaena & $\left\{\begin{array}{l}7120 \\
7119 \\
6411\end{array}\right.$ & $\begin{array}{l}1780 \\
1321 \\
1548\end{array}$ & $\begin{array}{l}5 \cdot 4 \\
7 \cdot 2 \\
6 \cdot 2\end{array}$ & $\begin{array}{l}5 \cdot 8 \\
7 \cdot 4 \\
6 \cdot 0\end{array}$ & $\begin{array}{l}40 \\
40 \\
37\end{array}$ \\
\hline IV & Nostoc & 6719 & 1183 & $8 \cdot 1$ & $8 \cdot 8$ & 43 \\
\hline
\end{tabular}

* Approximate values only; the genetic complexity of strain 7305 was not accurately determined because the excessive quantity of rapidly renaturing DNA prevented the establishment of true second-order renaturation kinetics of the main genome.

\section{Genome sizes of cyanobacteria assigned to Section $V$}

Section V (Table 5 and Fig. $1 e$ ) contains those heterocystous cyanobacteria which divide in more than one plane. The genera Chlorogloeopsis and Fischerella display complex morphological forms and produce hormogonia and akinetes (Rippka et al., 1979). Both show a wide intrageneric diversity in genome size which is not accompanied by variation in other phenotypic properties within the members of each genus. Although Chlorogloeopsis and Fischerella differ markedly in structural respects their overall ranges of genome sizes are similar $\left(4.20 \times 10^{9}\right.$ to $5.24 \times 10^{9}$ daltons and $3.62 \times 10^{9}$ to $4.75 \times 10^{9}$ daltons, means $4 \cdot 74 \times 10^{9}$ and $4.24 \times 10^{9}$ daltons, respectively).

\section{Rapidly renaturing fractions in cyanobacterial $D N A$}

Rapidly renaturing fractions were found in 13 strains of cyanobacteria. The data for these strains are shown in Table 6 , and representative examples of renaturation kinetics of reiterated DNA from strains of six genera are compared with related strains not possessing reiterated sequences in Fig. 2. The kinetic complexity of such fractions varied from $1.6 \times 10^{6}$ to $3.5 \times 10^{7}$ daltons, and the number of copies varied from 24 to 76 per single copy of the major chromosomal fraction. In most strains, the rapidly renaturing fractions represented 


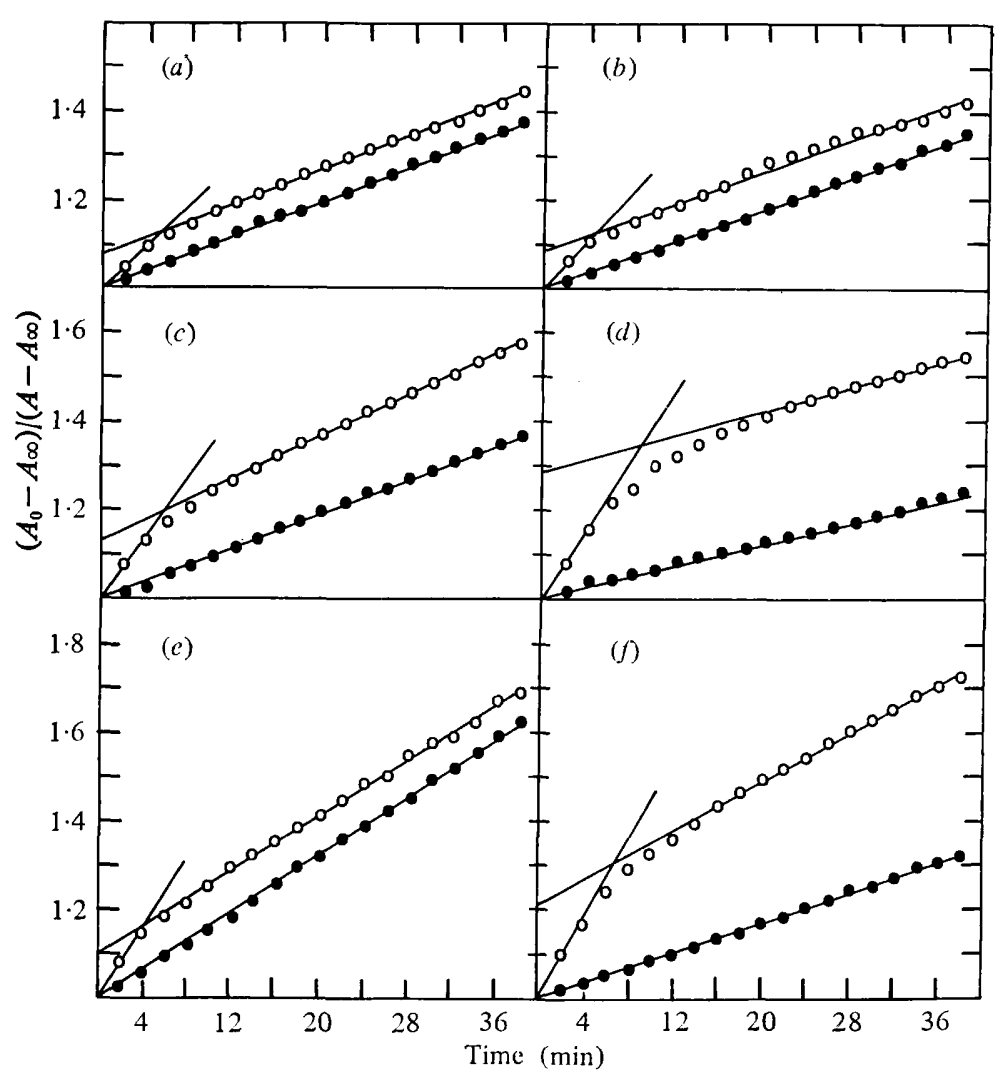

Fig. 2. Rapidly renaturing fractions in the DNA of strains from six cyanobacterial genera. For each genus a strain of similar genome size, exhibiting normal second-order renaturation kinetics, is also shown (O). (The concentration of DNA in each test solution, expressed in $\mu \mathrm{g} \mathrm{ml}^{-1}$, is shown in parenthesis.) (a) Anabaena: $\bigcirc, 7119$ (46.1); ○, 7118 (44.2). (b) Gloeocapsa: $\bigcirc, 73106$ (29.7); ○, 7428 (37.3). (c) Oscillatoria: $\bigcirc, 6412(48 \cdot 2)$;, $6602(44 \cdot 2)$. (d) LPP group: $\bigcirc, 7375(42 \cdot 2) ; 0$, 7420 (31.4). (e) Synechocystis: O, $6701(39 \cdot 4) ; 0,6808$ (43.2). (f) Xenococcus: O, $7305(43 \cdot 5)$; , $7307(43 \cdot 4)$.

between 5 and $12 \%$ of the total genome; cyanophages have not been detected in cells of these strains. In strains 7406 and 7375 (LPP group) and 7305 (Xenococcus) the rapidly renaturing fractions represented a significantly greater proportion (20 to $24 \%)$ of the total cell DNA; cyanophage-like structures have been observed in electron micrographs of strains 7305 (J. B. Waterbury, personal communication) and 7406 (G. Guglielmi, personal communication) and may be the source of the rapidly renaturing fractions. The nature of such fractions in the DNA isolated from the remaining 11 strains remains to be determined.

\section{The evolution of cyanobacterial genomes}

Cyanobacteria constitute the largest, most diverse and most widely distributed group of photosynthetic prokaryotes (Stanier \& Cohen-Bazire, 1977). They also show a remarkable range of genetic complexity; the lower limit of cyanobacterial genome size $\left(1.6 \times 10^{9}\right.$ daltons $)$ is similar to that of other bacteria but the upper limit $\left(8.6 \times 10^{9}\right.$ daltons $)$ far exceeds the largest genome previously described in prokaryotes.

The results suggest that, within the cyanobacteria as a whole, there is a correlation between genome size and morphological complexity, since strains which exhibit a high degree of morphological differentiation almost invariably possess genomes which are larger 


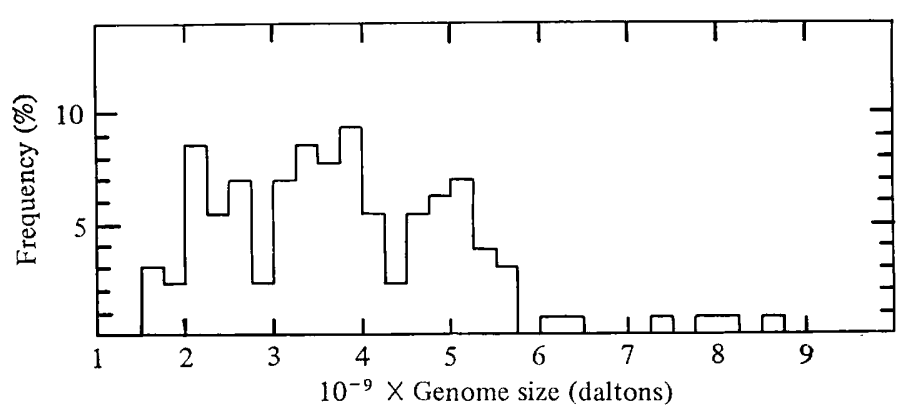

Fig. 3. Frequency distribution of cyanobacterial genome sizes.

than those of strains which display more simple morphological forms. The genome sizes of all 128 strains of cyanobacteria examined are shown in Fig. 3. The distribution is discontinuous: the genomes fall into four discrete groups which occupy the ranges $\left(\times 10^{9}\right.$ daltons $)$ : 1.6 to $2 \cdot 9,2 \cdot 9$ to $4 \cdot 4,4 \cdot 4$ to 5.8 and $6 \cdot 0$ to $8 \cdot 8$, respectively. The first three of these groups each contain a large number of strains (34, 52 and 36, respectively) and show no internal discontinuities. The fourth contains only six strains, of markedly different genome sizes, and may possibly represent several further groups; the limited number of strains available does not permit the immediate further resolution of this group.

The mean genome sizes of the four groups are $\left(\times 10^{9}\right.$ daltons \pm standard deviation): $2 \cdot 21 \pm 0 \cdot 31,3 \cdot 56 \pm 0 \cdot 37,5 \cdot 00 \pm 0 \cdot 39$ and $7 \cdot 40 \pm 0 \cdot 95$. These values correspond closely to those which would be obtained by a process of genome evolution involving a series of fusions of a smaller ancestral genome of $1.2 \times 10^{9}$ daltons, creating genomes containing two $\left(2.4 \times 10^{9}\right.$ daltons), three $\left(3.6 \times 10^{9}\right.$ daltons $)$, four $\left(4.8 \times 10^{9}\right.$ daltons $)$ and six $\left(7 \cdot 2 \times 10^{9}\right.$ daltons $)$ copies of the ancestral genome. The redundant DNA so created would be available for the development of new genetic information by mutation, permitting the subsequent evolution of a diversity of morphological forms.

This mechanism of genome evolution has been proposed previously to account for genome structure in other bacteria. Wallace \& Morowitz (1973) suggested, from the frequency distribution of bacterial genome sizes, that the genome of Acholeplasma (mean size $1.0 \times 10^{9}$ daltons) arose by duplication of a Mycoplasma genome of $0.5 \times 10^{9}$ daltons, and that the more complex (larger) genomes of other bacteria arose by further duplication. This proposal was supported by the analysis of the positions of related genes on the $E$. coli genetic map which suggested that the genome had arisen by one or two duplications of a smaller ancestral genome (Zipkas \& Riley, 1975). The present results support the hypothesis of genome evolution by duplication and suggest that it may have occurred in many different prokaryotic groups. The results further suggest an evolutionary mechanism by which the complex morphological organization characteristic of many cyanobacteria may have arisen.

The authors are grateful to Mme Josette Deruelles for help in providing the cell material, and to Dr John Waterbury for providing purified DNA samples from many cyanobacteria of Section II. We also thank Dr John Waterbury and M. Gerard Guglielmi for access to electron micrographs, and Dr Noel Carr for valuable comments on the manuscript. M.H. acknowledges receipt of a European Science Exchange Programme Fellowship from The Royal Society. The work was in part supported by the Centre National de la Recherche Scientifique (E.R.A. 398). 


\section{REFERENCES}

Bak, A. L., Black, F. T., Christiansen, C. \& FreundT, E. A. (1969). Genome size of mycoplasmal DNA. Nature, London 224, 1209-1210.

BaK, A. L., Christiansen, C. \& Stenderup, A. (1970). Bacterial genome sizes determined from DNA renaturation studies. Journal of General Microbiology 64, 377-380.

Burton, K. (1956). A study of the conditions and mechanism of the diphenylamine reaction for the colorimetric estimation of DNA. Biochemical Journal 62, 315 323 .

GILlis, M. \& DE LEY, J. (1975). Determination of the molecular complexity of double-stranded phage genome DNA from initial renaturation rates. The effect of DNA base composition. Journal of Molecular Biology 98, 447-464.

Gillis, M., De Ley, J. \& DeCleene, M. (1970). The determination of molecular weight of bacterial genome DNA from renaturation rates. European Journal of Biochemistry 12, 143-153.

Herdman, M. \& Carr, N. G. (1974). Estimation of the genome size of blue-green algae from DNA renaturation rates. Archives of Microbiology 99, 251 254.

Herdman, M., Janvier, M., Waterbury, J. B., RipPKa, R., Stanier, R. Y. \& MANDEL, M. (1979). Deoxyribonucleic acid base composition of cyanobacteria. Journal of General Microbiology 111, 63-71.

Kung, S. D., Moscarello, M. A. \& Williams, J. P. (1972). Studies with deoxyribonucleic acid from blue-green algae. Plant Physiology 49, 331334.

ManN, N. \& Carr, N. G. (1974). Control of macromolecular composition and cell division in the blue-green alga Anacystis nidulans. Journal of General Microbiology 83, 399-405.

Marmur, J. \& DotY, P. (1962). Determination of the base composition of deoxyribonucleic acid from its thermal denaturation temperature. Journal of Molecular Biology 5, 109-118.

Pemberton, J. M. (1974). Size of the chromosome of Pseudomonas aeruginosa PAO. Journal of Bacteriology 119, 748-752.
RIPPKA, R. \& WATERBURY, J. B. (1977). The synthesis of nitrogenase by non-heterocystous cyanobacteria. FEMS Microbiology Letters 2, 83-86.

Rippka, R., Deruelles, J., WATERbury, J. B., Herdman, M. \& Stanier, R. Y. (1979). Generic assignments, strain histories and properties of pure cultures of cyanobacteria. Journal of General Microbiology 111, 1-61.

Roberts, T. M., Klotz, L. C. \& Loeblich, A. R. (1977). Characterisation of a blue-green algal genome. Sournal of Molecular Biology 110, 341361 .

St Am, W. T. \& Venema, G. (1977). The use of DNADNA hybridization for determination of the relationship between some blue-green algae (Cyanophyceae). Acta botanica neerlandica $\mathbf{2 6}$ 327-342.

Stanier, R. Y. \& CoHen-Bazire, G. (1977). Phototrophic prokaryotes: the cyanobacteria. Annual Review of Microbiology 31, 225-274.

Stanier, R. Y., Kunisawa, R., Mandel, M. \& Cohen-Bazire, G. (1971). Purification and properties of unicellular blue-green algae (order Chroococcales). Bacteriological Reviews 35, 171205.

Wallace, D. C. \& Morowitz, H. J. (1973). Genome size and evolution. Chromosoma 40, 121126.

WATERbury, J. B. \& Stanier, R. Y. (1977). Two unicellular cyanobacteria which reproduce by budding. Archives of Microbiology 115, 249-257.

WATERbURy, J. B. \& STANIER, R. Y. (1978). Patterns of growth and development in pleurocapsalean cyanobacteria. Bacteriological Reviews 42, 2-44.

WetMur, J. G. \& Davidson, N. (1968). Kinetics of renaturation of DNA. Journal of Molecular Biology 31, 349-370.

ZIPKAS, D. \& RILEY, M. (1975). Proposal concerning the evolution of the genome of Escherichia coli. Proceedings of the National Academy of Sciences of the United States of America 72, 1354-1358. 